\title{
Predictable biomarkers in acute cerebral ischemic stroke
}

\section{Biomarkeri predictibili în accidentul vascular cerebral ischemic acut}

Eliza CETEAN ${ }^{1,2}$, Silviu Daniel MOLDOVAN ${ }^{1,2}$, Romana Olivia POPEȚIU ${ }^{1,2}$, Oana Lucia AMZA ${ }^{1,2}$, Maria PUŞCHIȚĂ ${ }^{1,2}$

${ }^{1}$ Facultatea de Medicină, Universitatea de Vest „Vasile Goldiș“, Arad, România

${ }^{2}$ Spitalul Clinic Județean de Urgență, Arad, România

\section{ABSTRACT}

Stroke is the second leading cause of death in patients over 60 years of age, being the most important cause of disability. Biomarkers provide essential information about the main biological processes that occur during cerebral ischemia. Used correctly can positively influence the management in the acute vascular accidents.

Keywords: acute ischemic stroke, biomarkers, high sensitive PCR, lipoproteinfospholipase A2

\begin{abstract}
REZUMAT
Accidentul vascular reprezintă a doua cauză de deces la pacienții cu vârsta de peste 60 ani, fiind cea mai importantă cauză de dizabilitate. Biomarkerii oferă informații critice despre procesele biologice cheie care au loc în timpul ischemiei cerebrale. Folosiți corect, pot influența pozitiv managementul accidentelor vasculare cerebrale acute.
\end{abstract}

Cuvinte cheie: accident vascular cerebral ischemic acut, biomarkeri, PCR înalt senzitiv,

lipoproteinfosfolipaza A2

\section{INTRODUCERE}

Accidentul vascular reprezintă a doua cauză de deces la pacienții cu vârsta de peste 60 ani, fiind cea mai importantă cauză de dizabilitate. Din totalul cheltuielilor din sistemul medical, sunt folosite aproximatix 3-7\% pe aceste afecțiuni neurologice $(3,4,5)$. Până în 2050 , se preconizează a fi peste 1,5 miliarde de oameni care vor împlini vârsta de 65 ani, anunțându-se deja o iminentă epidemie silențioasă de accidente vasculare.

Fiziopatologia ischemiei cerebrale joacă un rol important în cercetarea biomarkerilor din accidentele cerebrale. Date importante indică faptul că ateroscleroza este o boală cu debut insidios, care crește numărul de boli cerebrovasculare. Accidentul vascular ischemic este consecința aterosclerozei ce afectează vasele mari intra- și extracerebrale și vasele mici, dar și rezultatul unui fenomen embolic, având drept consecință o întrerupere sau o reducere severă a fluxului sanguin cerebral. În funcție de gradul de hipoperfuzie, zona care este privată complet de flux sanguin se numește zonă de ischemie, unde are loc moartea neuronală în câteva minute; zona delimitantă se numește penumbră, aceasta suferind de o reducere a fluxului sanguin și conține țesut cerebral semi funcțional $(6,7,8)$.

Tratamentul pentru AVC ischemic acut este reprezentat de recanalizarea și reperfuzia prin trom- 
boliză sau tratament endovascular. Reperfuzia cât mai precoce are un potențial mare de a salva țesutul cerebral ischemic. Cascada ischemică este caracterizată prin următoarele evenimente biochimice: tulburări electrolitice, acidoză, excitotoxicitate, stres oxidativ și inflamație, culminând cu moartea celulară via necroză și apoptoză. În practica medicală, beneficiile revascularizației sunt foarte atent gândite din cauza riscului de hemoragie intracraniană asociată cu deteriorare neurologică precoce și grad ridicat de mortalitate (9-12).

\section{CE SUNT BIOMARKERII?}

Biomarkerii oferă informații critice despre procesele biologice cheie care au loc în timpul ischemiei cerebrale. Folosiți corect, pot influența pozitiv managementul accidentelor vasculare cerebrale acute. Corelația unor biomarkeri din sânge pentru accidentul vascular cerebral (AVC) acut și translația lor în practica medicală este foarte dificilă, în parte din cauza complexității patogenezei accidentului vascular ischemic acut și prezenței barierei hemato-encefalice, care restricționează eliberarea unor markeri cerebrali specifici în circulație $(1,2)$.

Biomarkerii sunt semnături biologice ale unor procese normale sau patologice care pot servi pentru numeroase scopuri cum ar fi: strategii terapeutice, dezvoltarea de noi medicamente sau cercetare clinică. Biomarkerul are o importanță clinică favorabilă și este ușor de interpretat de către clinician dacă prezintă specificitate și sensibilitate crescută pentru rezultatul ce urmează a fi identificat și dacă a mai fost folosit și în alte studii de cercetare. Sursa biomarkerilor este la fel de importantă, urmărind ischemia cerebrală, urmată de activarea răspunsului inflamator, putând distinge celule inflamatorii ce eliberează citokine proinflamatorii cum ar fi interleukina 6, PCR înalt senzitivă, lipoproteinfosfolipaza A2, fibrinogenul, d-dimerii la pacienții cu risc cardiovascular și enolaza neuron specifică, ale căror valori crescute în sânge care pot indica prezența infarctului cerebral (13, 14).

Biomarkerii pot fi clasificați în funcție de aplicația clinică. În AVC ischemic, studiile au evaluat biomarkeri pentru a determina etiologia accidentului vascular, putând prezice severitatea și complicațiile ulterioare și, nu în ultimul rând, pentru a identifica pacienții care pot beneficia de hemicraniotomie decompresivă. Numeroase studii au examinat importanța acestor biomarkeri pentru a evalua prognosticul pacienților, cum ar fi recuperarea funcțională sau evenimente vasculare recurente. Unii cercetători au investigat biomarkeri care pot estima gradul de infarctizare și au găsit asocieri semnificative între acest grad de infarctizare și interleukina 6, factorul de necroză tumoral, metalopeptidaza 9 și S100 beta (15-18).

Biomarkerii au un rol important în a identifica pacienții cu risc înalt de accidente neurologice, de exemplu nivelurile plasmatice crescute ale glutamatului $>200 \mu \mathrm{mol} / \mathrm{l}$, ce pot diagnostica deterioarea neurologică precoce la pacienții cu AVC emisferic. PCR înalt senzitivă este un marker inflamator care, alături de HDL și în prezența unei ocluzii de arteră carotidă, poate fi asociat cu accidentul vascular ischemic (19).

Markerii endoteliali - precum dimetilarginina (care in vivo este un inhibitor endogen al sintezei de oxid nitric) - au fost asociați cu ateroscleroza și factori de risc pentru AVC. Un studiu efectuat pe pacienți cu AVC ischemic a demonstrat modificări semnificative ale dimetilargininei asimetrice și ale dimetilargininei simetrice după AVC, cu creșterea acestora la 72 ore după accidentul vascular, cu un prognostic slab de recuperare funcțională (20).

\section{CONCLUZII}

Biomarkerii serologici oferă informații importante despre evenimentele patologice ce pot duce la infarctul cerebral și joacă un rol cheie în managementul accidentului vascular cerebral. Este necesar a se efectua și studii clinice de cohortă standardizate și metode analitice încorporând dozarea acestor biomarkeri, pentru a oferi un punct de vedere în decizia clinică a accidentelor vasculare. Având în vedere heretogenitatea tot mai mare a accidentelor vasculare, folosirea doar a unui biomarker nu este suficientă pentru toate aspectele patogenice din AVC. Corelația biomarkerilor din accidentul vascular cerebral în practica medicală reprezintă o provocare, dar poate fi extrem de benefică, având în vedere eforturile cercetătorilor și clinicienilor pentru un prognostic pozitiv al acestor pacienți. 


\section{BIBLIOGRAFIE}

1. Lo EH, Moskowitz MA, Jacobs TP. Exciting, radical, suicidal: how brain cells die after stroke. Stroke 2005;36:188-93.

2. Astrup J, Siesjo BK, Symon L. Thresholds in cerebral ischemia - the ischemic penumbra. Stroke 1981;12:723-5.

3. Tissue plasminogen activator for acute ischemic stroke. The National Institute of Neurological Disorders and Stroke rt-PA Stroke Study Group. N Engl J Med 1995; 333:1581-7.

4. Powers WJ, Derdeyn CP, Biller J, et al. 2015 American Heart Association/American Stroke Association Focused Update of the 2013 Guidelines for the Early Management of Patients With Acute Ischemic Stroke Regarding Endovascular Treatment: A Guideline for Healthcare Professionals From the American Heart Association/ American Stroke Association. Stroke 2015; 46:3020-35.

5. Khatri R, McKinney AM, Swenson B, Janardhan V. Blood-brain barrier, reperfusion injury, and hemorrhagic transformation in acute ischemic stroke. Neurology. 2012 Sep 25; 79(13 Suppl 1):S52-7.

6. Seet RC, Rabinstein AA. Symptomatic intracranial hemorrhage following intravenous thrombolysis for acute ischemic stroke: a critical review of case definitions. Cerebrovasc Dis 2012;34:106-14.
7. Biomarkers Definitions Working G. Biomarkers and surrogate endpoints: preferred definitions and conceptual framework. Clin Pharmacol Ther 2001; 69:89-95.

8. Muir KW. Heterogeneity of stroke pathophysiology and neuroprotective clinical trial design. Stroke 2002; 33:1545-50.

9. Hink HU, Santanam N, Dikalov S et al. Peroxidase properties of extracellular superoxide dismutase: role of uric acid in modulating in vivo activity. Arterioscler Thromb Vasc Biol 2002;22:1402-8.

10. 10. Worthmann H, Chen S, MartensLobenhoffer J, et al. High plasma dimethylarginine levels are associated with adverse clinical outcome after stroke. J Atheroscler Thromb 2011;18:753-61.

11. Bandeali S, Farmer J. High-density lipoprotein and atherosclerosis: the role of antioxidant activity. Current atherosclerosis reports 2012;14:101-7.

12. Laskowitz DT, Blessing R, Floyd J, White WD, Lynch JR. Panel of biomarkers predicts stroke. Ann N Y Acad Sci 2005; 1053:30.

13. Barr TL, Latour LL, Lee KY et al. Bloodbrain barrier disruption in humans is independently associated with increased matrix metalloproteinase-9. Stroke 2010; 41:e123-8.
14. Whiteley W, Chong WL, Sengupta A, Sandercock P. Blood markers for the prognosis of ischemic stroke: A systematic review. Stroke 2009; 40:e380-9.

15. Seet RC, Kasiman K, Gruber J et al. Is uric acid protective or deleterious in acute ischemic stroke? A prospective cohort study. Atherosclerosis 2010;209:215-9.

16. Ballantyne CM, Hoogeveen RC, Bang $\mathrm{H}$ et al. Lipoprotein-associated phospholipase A2, high-sensitivity C-reactive protein, and risk for incident ischemic stroke in middle-aged men and women in the Atherosclerosis Risk in Communities (ARIC) study. Arch Intern Med 2005; 165:2479-84.

17. Elkind MS, Tai W, Coates K, Paik MC, Sacco RL. Lipoprotein-associated phospholipase A2 activity and risk of recurrent stroke. Cerebrovasc Dis 2009; 27:41-51.

18. Gorelick PB. Lipoprotein-associated phospholipase A2 and risk of stroke. Am J Cardiol 2008;101:34F-40F.

19. Hijazi Z, Lindback J, Alexander JH et al. The ABC (age, biomarkers, clinical history) stroke risk score: a biomarker-based risk score for predicting stroke in atrial fibrillation. Eur Heart J 2016;37:1582-90.

20. Rosenson RS, Lowe GD. Effects of lipids and lipoproteins on thrombosis and rheology. Atherosclerosis 1998;140:271-80. 